\title{
The Effect of Tourist Facilities on Visitor Satisfaction in Tourist Attractions in Pamutusan Island, Bungus West Sumatera
}

\author{
Yuzia Eka Putri ${ }^{1}$, Fatma Tresno Ingtiyas ${ }^{2}$ \\ Universitas Negeri Medan, Indonesia ${ }^{1,2}$ \\ e.yuzia@yahoo.com ${ }^{1}$
}

\begin{abstract}
This research is motivated by the price of the package complained about being quite high because it is not in accordance with the facilities and tourist attractions on the island of Pamutusan. Bad condition tourist attraction facilities, such as open wells and the beach area look dirty because of the scattered garbage. This article aims to reveal the factual effect of tourist facilities on visitor satisfaction in the tourist attraction of the island of Pamutusan West Sumatra. This type of research is causal associative. The population in this study is visitors to Pamutusan Island with 100 respondents. Data analysis techniques using in this study is analysis of the level of respondents' achievement, the test of classical assumptions and hypothesis testing. The results showed the TCR for the facility variable obtained a TCR of $77.20 \%$ with a sufficient category. It would be better if the addition of facilities that do not yet exist and the improvement of facilities that are in poor condition. While the visitor satisfaction variable gets TCR $80 \%$ in the good category. Regression test results showed the value of the analysis results known $t$ count $=-3.031$ with sig $=0.003$ $<0.05$. This means that there is an influence between facilities on visitor satisfaction in tourist attractions on the island of Pamutusan.
\end{abstract}

Keywords: facilities, and visitor satisfaction

\section{Introduction}

Indonesia is an archipelago that has more than 13,466 islands. This condition causes Indonesia to become one of the destinations of local and different tourists because of the beautiful and unique tourist attractions and culture, where each island has a different beauty from the island that includes small islands in the region of West Sumatra.

West Sumatra with a city center structure that is spread along the coast and has islands scattered around it so that it provides potential as an area for tourist areas. Island tourism is currently an alternative to meeting the needs for recreation and tourism. Previously the island's only known tour was Sikuai Island, but the fishermen in the area tried to search the islands around the Bungus area and found Pagang and Pamutusan Island, that has more beautiful views than Sikuai Island. The beauty of the island is like soft white sand beach and blue water and surrounded by coconut trees around the beach and verdant mangrove. From the surface of the beach fish that are swimming can be seen. On the mainland coast there is a plateau in the form of a small hill. Visitors can enjoy the beauty of the beach from the top of the hill. 
At present the existence of small islands is beginning to be known because fishermen have sought the introduction of the island among the most prominent communities to the students. Since 2012 until now there has been an increase in visitors continuously until travel agents are on the rise doing promotions by offering a variety of packages to these islands. This attempt was done because of seeing tourists' interest in island tourism is very high, especially among teenagers and With the potential beauty of the students, Pamutusan Island can be famous if the government intervenes in completing tourism facilities and promoting tourism.

Visitors who travel to Pamutusan Island can snorkel while taking pictures in the water. This activity is one of the tourist attractions in Pamutusan. The travel agent also helped provide snorkeling equipment and cameras used for diving. The following is a list of the levels of visits in Pamutusan Island in the past year:

Table. 1 List of visits in Pamutusan Island in 2015

\begin{tabular}{lc}
\hline Month & Number of visitors \\
\hline January & 511 \\
February & 543 \\
Marc & 390 \\
April & 501 \\
Mei & 350 \\
June & 590 \\
July & 551 \\
August & 91 \\
September & 349 \\
October & 547 \\
November & 559 \\
December & 563 \\
\hline
\end{tabular}

Based on the table the number of visitors to Pamutusan Island from observations shows that the number of visitors is almost a lot every month, reaching 590 people and also with the use of attractions such as snorkeling facilities, underwater photos, and boats. The graph of visitor growth can be described as follows:

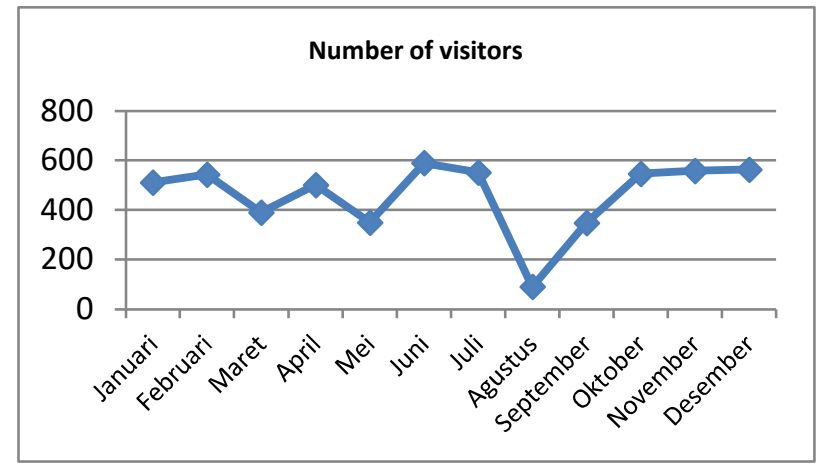

Fig 1. The number of visitors to the tourist attraction in the island of Pamutusan 2015

The graph above shows the movement of the number of visitors each month. Surge in visitors there in the holiday season, namely June. Drastic decline in visitors was found in 
August. This is due in August Muslims entered the fasting month. Looking at the number of visit data that is quite a lot, it is unfortunate if the condition of the island is not equipped with tourist support facilities.

Ideally, visitors who come want a clean tourist environment. But in reality, based on preliminary observations of the current condition of the islands, the scattered areas are not properly considered by the management. There is a little rubbish. The waste is also left scattered around the coastal environment, so that the beauty of the beach is reduced. Like the picture 2 below:
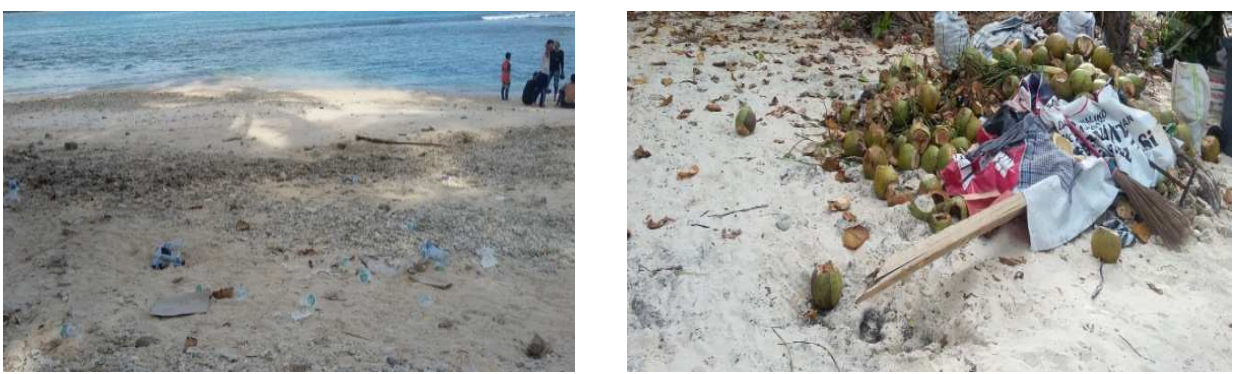

Fig 2. Dirty beach conditions with plastic waste and coconut waste

The picture above shows the beach environment that looks dirty. Besides that the facilities available are also far from good category. The toilet is provided in an open state. There is only well in an open state, sometimes surrounded by tarpaulin. So that when visitors want to clean the body of visitors is not comfortable with existing conditions.

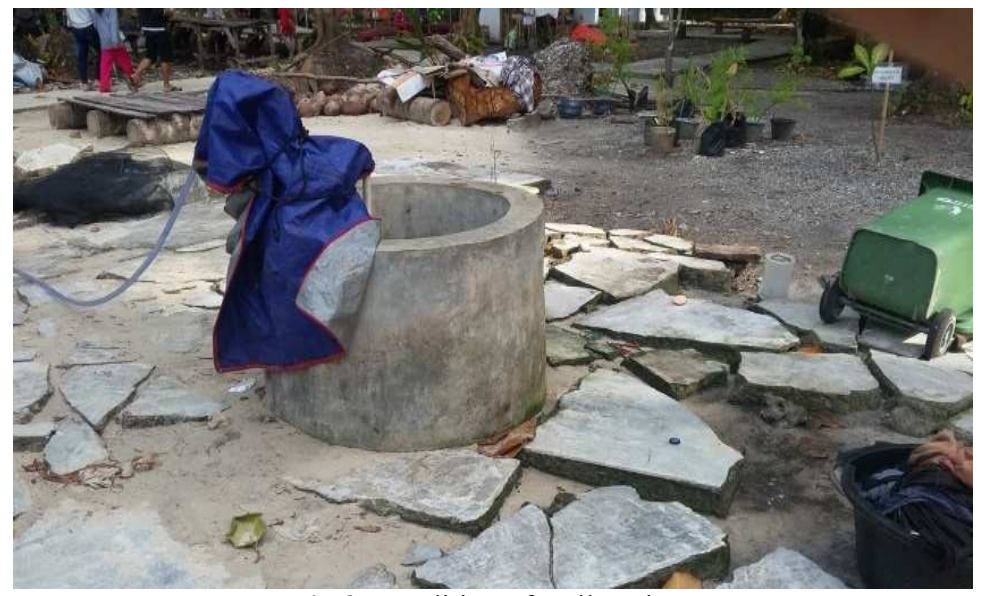

Fig 3. Condition of well to rinse

The picture above illustrates the condition of one of the facilities on the island of Pamutusan. Furthermore, some snorkeling equipment is also in poor condition. As Figure 4 below: 


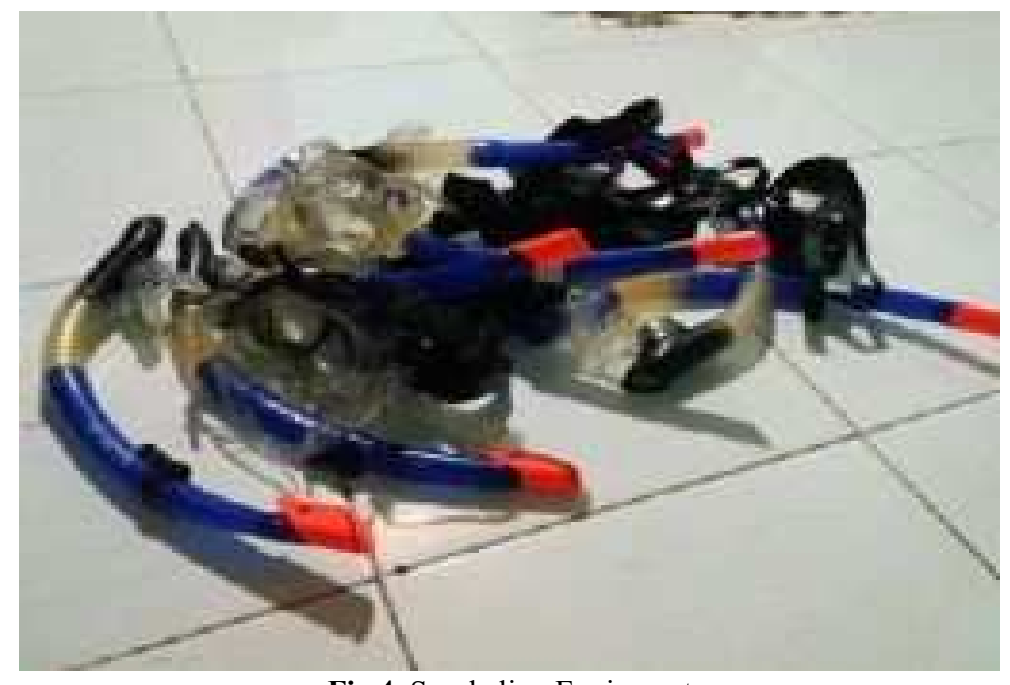

Fig 4. Snorkeling Equipment

Figure 4 above shows a number of snorkeling equipment, some of which are in poor condition. The color is worn and rubber equipment that is damaged is only replaced using ordinary rubber. This snorkeling equipment is rented by a travel agent if there are visitors who use tour packages to visit Pamutusan Snorkeling equipment provided by travel agents is not proportional to the number of visitors there. As a result the use of snorkeling equipment must be used interchangeably. This is not in accordance with the expectations of visitors, even though visitors have incurred a large enough cost to be able to travel to the island. Problems such as those described above are very hindering for the development of tourist attractions as stated by Suwantoro [1]: "The main elements that must receive attention in order to support the development of tourism in tourist destinations, include: (1) Tourism Objects and Attractions (ODTW), (2) Tourism Infrastructure, (3) Tourism Facilities, (4) Governance (services, security, and comfort) (5) Community / Environment ".

Facilities obtained by visitors are felt inappropriate, in the end visitors complained about the high price spent to get to the island's attractions. One of the tourists who had visited Pamutusan Island stated that they were satisfied with the view of the coast of Pamutusan Island, and felt disappointed with the environment that was not preserved.

In terms of access to the island visitors feel quite difficult. To achieve this, visitors are offered two options, namely to use island tour packages sold by travel agents or using the services of fishermen. If you use the service of visitors only costs approximately Rp. 100,000. At that price, visitors get around trip transportation, swimming equipment, and island entrance tickets. But visitors must gather a minimum of 15 members and security is not available. The vehicle used is the fishing boat. If visitors to the island use the services of a travel agent, visitors must spend a significant amount each person for a day trip with transportation facilities to the island, lunch, and swimming equipment. The following is a list of prices given by travel agents: 
Table 2. List price of Pamutusan Island Tour through Travel Agent

\begin{tabular}{lcl}
\hline \multicolumn{1}{c}{ Agent Name } & $\begin{array}{c}\text { Price } \\
\text { (Rp) }\end{array}$ & \multicolumn{1}{c}{ Facilities } \\
\hline Duta Wisata Pesona & 280.000 & 1. boat transportation, lunch (rice box / wrap) + mineral \\
& & water, \\
& 2. banana boat, snorkeling, underwater photos, island entrance \\
tickets & 3. Coffe break \\
\hline Sartika Dewi & 270.000 & 1. boat transportation, lunch (rice box / wrap) + mineral \\
& water. \\
& 2. banana boat, snorkeling, underwater photos, island \\
& entrance tickets \\
& 3. Coffe break (kopi / teh panas) \\
\hline Raminang Tour & 1. Ac ship and round trip \\
& 2. Entrance ticket to the island \\
& 3. The life jacket \\
& 4. Lunch (rice wrap / box) + mineral water \\
& 5. Coffee break (hot tea / hot coffee) \\
& 6. Free banana boat \\
& 7. Snorkeling + underwater photos \\
& 8. Safety first aid \\
& 9. Travel Insurance \\
\hline
\end{tabular}

From the city of Padang visitors must first go to Sungai Pisang, then can use a boat to islands. The struggle to get to the Banana River is not easy. Visitors must pass through a very steep and punchy road. If visitors choose a package offered by the travel agent, they use a motorboat to access transportation to the islands, of course, using a higher cost than using the services of fishermen. Complaints of high prices felt by visitors when using the services of this travel agent. They complained about tourist facilities that did not match the price they paid.

Based on preliminary observations of various visitors to the island's tourist attractions, the problems related to prices and facilities mentioned above caused visitors to feel less satisfied. Visitors compare the costs incurred with the acquisition of facilities at tourist attractions. This is in line with Tjiptono [2] that states that satisfaction is the consumer's response to the perceived evaluation between previous expectations and the actual performance of the product that is felt after its use. The relationship between facilities and satisfaction has been proven by research conducted by Martianawati, Widitomo, Wijaya, where the results of the study are that facilities have an influence on satisfaction.

\section{Research Method}

This research uses quantitative methods. The data collection technique is in the form of a questionnaire that is arranged using a Likert scale. The research respondents numbered 100 people who visited the tourist attraction Pamutusan. The data analysis technique consisted of the level of respondents' achievement, the classical assumption test, and the hypothesis test. Presentation of quantitative data is in the form of tables and narratives. 


\section{Results and Discussion}

The results showed the average tourist facilities variable assessment given by 100 respondents as a whole was 3.86 with $77.2 \%$ of respondents' achievement level. The level of achievement of these respondents can be classified with enough categories. Then for the visitor satisfaction variable obtained an average rating given by 100 respondents as a whole is 3.99 with an $80 \%$ achievement rate of respondents. The level of achievement of these respondents can be classified in either category. Multiple regression analysis shows there is an influence of package prices and tourist facilities on the satisfaction of visitors to the tourist attraction. The contribution amount given by the variable price of packages and facilities to visitor satisfaction is $9.21 \%$ while the rest is explained by other factors outside the variable prices of packages and facilities. Significant positive correlation between tourist facilities on satisfaction 0.096 means that the more complete the facility, the higher the level of visitor satisfaction in tourist attractions on the island of Pamutusan.

Based on the results of hypothesis testing found that there is a significant influence of facility (X2) on visitor satisfaction (Y). Multiple regression analysis showed that $\mathrm{t}$ arithmetic $=$ -3.031 with $\operatorname{sig}=0.003<0.05$, indicating that the facility had a positive and significant effect on the satisfaction of visitors of tourist attractions. This means that facility factors can increase the satisfaction of visitors to tourist attractions.

\section{Conclusions and Suggestions}

Based on the results of research and discussion conducted through data analysis, it can be concluded:

1) The facilities available on Pamutusan Island are considered sufficient by 100 data respondents with an average score of 3.86 with a TCR of $77.20 \%$, like the rinse and toilet.

2) The satisfaction of visitors to the tourist attraction of the island of Pamutusan in the value enough by the visitors of the attractions seen from the average score of 3.99.

Based on the conclusions that have been put forward, then below are some suggestions that are expected to increase visitor satisfaction. The suggestions given for the island manager are as follows:

1) Maintain the price of the package, do additional tourist attractions on the island of Pamutusan such as flying boards, rolling donuts, flying fish, sea walkers, walker boarding so that visitors come back to the island of Pamutusan.

2) Add additional facilities, such as toilets, condition the number with visitors, repair rinse rooms, restaurants, trash bins, place of worship, beach umbrella etc.

3) Visitors are satisfied now to enjoy the beauty of the beach on the island of Pamutusan. This must be anticipated by the improvement of facilities and the addition of attractions so that visitors can come back to travel on the island of Pamutusan, with the acquisition of TCR 79\%. Package and facility prices affect visitor satisfaction. 


\section{References}

[1] Suwantoro, Gamal. Dasar-dasar Pariwisata. Yogyakarta: CV. Andi Offset. (1992)

[2] Tjiptono, Fandy dan Chandra, Gregorius. Sercive, Quality \& Satisfaction. Edisi Ketiga. Yogyakarta: ANDI. (2011)

[3] Wahmuji. Kamus Besar Bahasa Indonesia. Jakarta: PT Gramedia Pustaka Utama. (1991) 